\title{
THE WOODY FLORA OF CERRADO VEGETATION IN THE STATE OF PIAUí, NORTHEASTERN BRAZIL
}

\author{
A. A. J. F. CASTRO*, F. R. MARTINS $\dagger \&$ A. G. FERNANDES
}

Cerrado vegetation covers about $33 \%$ of the total area of the state of Piauí, northeastern Brazil, where there are also large areas of transition and contact with other vegetation types. Although the Piauí cerrados are a direct northern prolongation of the central core area, they are considered marginal by almost all authors. There are few previous records of their woody flora. This paper presents a floristic list of woody species based on the survey of 11 localities and updating of two already published lists. The climate belongs to Thornthwaite's subhumid category due to Piauís position between the semiarid northeastern domain and the superhumid Amazon. The annual total rainfall is similar to that of the major part of the Brazilian cerrado area, but the rainy season is shorter. The soils differ from most cerrado soils in containing a greater proportion of concretions and plinthite with generally lighter colours, which may be interpreted as indicating large fluctuations of the water-table during pedogenesis. There are also widespread indications of seasonal high water-table showing that many of the Piauí cerrados probably belong to Sarmiento's hyperseasonal savannah category. A total of 60 families is represented by 307 woody taxa (including 14 family indet., four genera indet. and 80 species indet.). The lowest floristic diversity (richness) occurred in pure cerrado, the greatest in transition and contact areas.

O cerrado do Piauí, nordeste do Brasil, cobre cerca de 33\% da área do estado e apresenta extensas áreas de transição e contato com outros tipos de vegetação. É um prolongamento setentrional do cerrado central, mas é considerado marginal. Sua flora lenhosa é pouco conhecida. Este trabalho apresenta uma lista florística lenhosa baseada em 11 levantamentos de campo e atualização de duas listas já publicadas. Os climas são subúmidos de Thornthwaite, em decorrência de sua localização entre o domínio semi-árido nordestino e o superúmido amazônico. O total anual de chuva é semelhante ao do resto do cerrado, mas a estação chuvosa é bem mais curta. Os solos são diferentes dos do restante dos cerrados, apresentando concreções, plintita e cores claras, indicando grandes flutuações do lençol freático durante a pedogênese. As grandes flutuações estacionais do lençol freático implicam em que boa parte do cerrado piauiense possa ser classificada como savana hiperestacional de Sarmiento. Apresenta-se um total de 60 famílias conhecidas e 308 táxons lenhosos ( 14 desconhecidos no nível de família, 4 desconhecidos no nível de gênero e 80 desconhecidos no nível de espécie). A menor diversidade (riqueza) florística ocorreu no domínio puro do cerrado; as maiores ocorreram nas áreas de transição.

* Departamento de Biologia, Centro de Ciências da Natureza, Universidade Federal do Piauí, Teresina 64049-550, PI, Brasil.

† Departamento de Botânica, Instituto de Biologia, Universidade Estadual de Campinas, Caixa Postal 6109, Campinas 13083-970, SP, Brasil.

‡ Departamento de Biologia, Centro de Ciências, Universidade Federal do Ceará, Fortaleza 60455-760, $\mathrm{CE}$, Brasil. 


\section{INTRODUCTION}

The state of Piauí is located in the northeastern region of Brazil (Fig. 1) and has a total area of $25,093,400 \mathrm{ha}$ of which about $33.3 \%(8,349,759 \mathrm{ha})$ is covered by cerrado vegetation sensu lato, and $14.0 \%(3,507,107 \mathrm{ha})$ represents transition and contact areas of cerrado with other types of vegetation: caatinga (dry thorn woodland and shrubland), carrasco (dry cerrado-caatinga transition), dry deciduous forest, seasonal subdeciduous forest, Orbignya palm forest, riparian forest and grasslands (CEPRO, 1992). Cerrado constitutes the second most extensive type of vegetation in the state; its area is only exceeded by that of the caatinga.

Although the cerrado area in the state of Piauí is a direct continuation of that of the core area on the Central Plateau of Brazil, it is generally considered marginal (e.g. Rizzini, 1963) since it is located at the northern extreme of the distribution area of the biome. There is little information available about its flora: only five relevant papers have so far been published, of which two (Goergen, 1983; Jenrich, 1989) did not have floristic survey as their main goal. Of the others, Rizzini (1976) produced a preliminary list of 61 species of angiosperms based on a single field survey and an examination of herbarium material, but Barroso \& Guimarães (1980) and Castro (1984) reported intensive field surveys. The present paper communicates the results of surveys of some representative areas in the state.

\section{MATERIALS AND METHODS}

Eleven different localities (locs. 102 and 121-130, Fig. 1) were surveyed by means of the plot method (Mueller-Dombois \& Ellenberg, 1974). The vegetation of all localities fell into the physiognomic class of cerrado sensu stricto (Coutinho, 1978); many were sited in regions of vegetation transition (principally between cerrado and deciduous forest or cerrado and caatinga).

In one locality (loc. 102) the area was surveyed by a systematic grid consisting of thirty $10 \times 20 \mathrm{~m}$ plots, $50 \mathrm{~m}$ apart, and all woody plants with at least one trunk with diameter at ground level $\geq 3 \mathrm{~cm}$ were recorded. All other localities (see Table 1 and caption of Fig. 1 for details) were sampled by single $20 \times 500 \mathrm{~m}$ ( 1 ha) plots on which all woody plants with at least one trunk of $\geq 5 \mathrm{~cm}$ DBH were recorded.

The species records of Barroso \& Guimarães (1980) from the Sete Cidades National Park (loc. 69, Fig. 1) and Castro (1984) from Uruçuí-Una Ecological Station (loc. 95) are also included to make the list as complete as possible. The identifications in the latter work have been updated. These authors used the 'preferential collecting' method (Castro, 1994), i.e., a general reconnaissance and collecting, or wide-patrolling or walking-and-gathering method, without setting any specific area or plant size limits. Arboreal and shrubby species have been selected from their lists, which also included species from the lower layers of vegetation.

Information on the geographic distribution of cerrado woody species was obtained from many references (e.g. Ratter et al., 1973; Heringer et al., 1977; Sarmiento, 1983; 


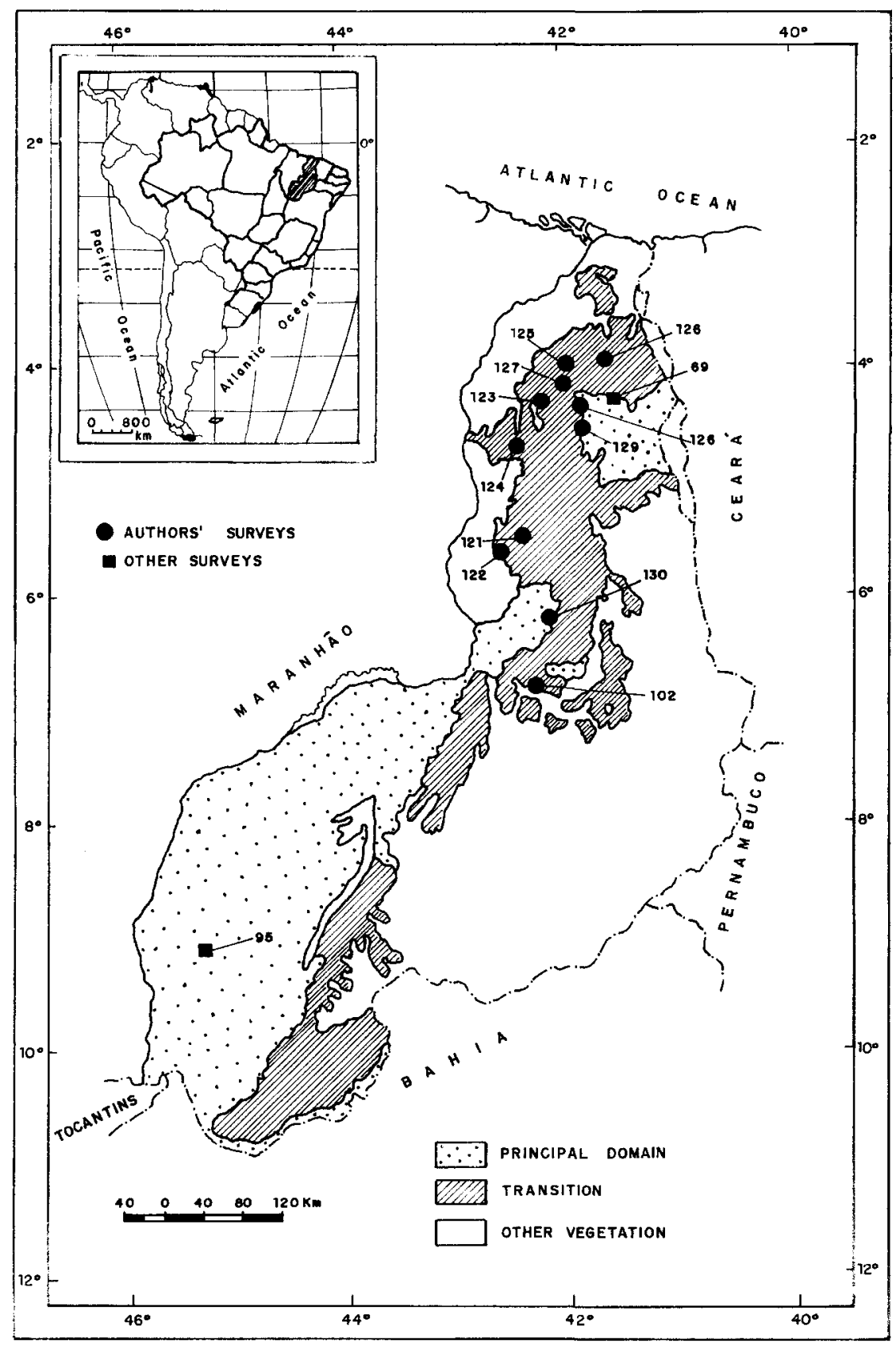

FIG. 1. Map of Piaui showing distribution of cerrado and transitional vegetation (CEPRO, 1992) and the positions of the survey localities. 


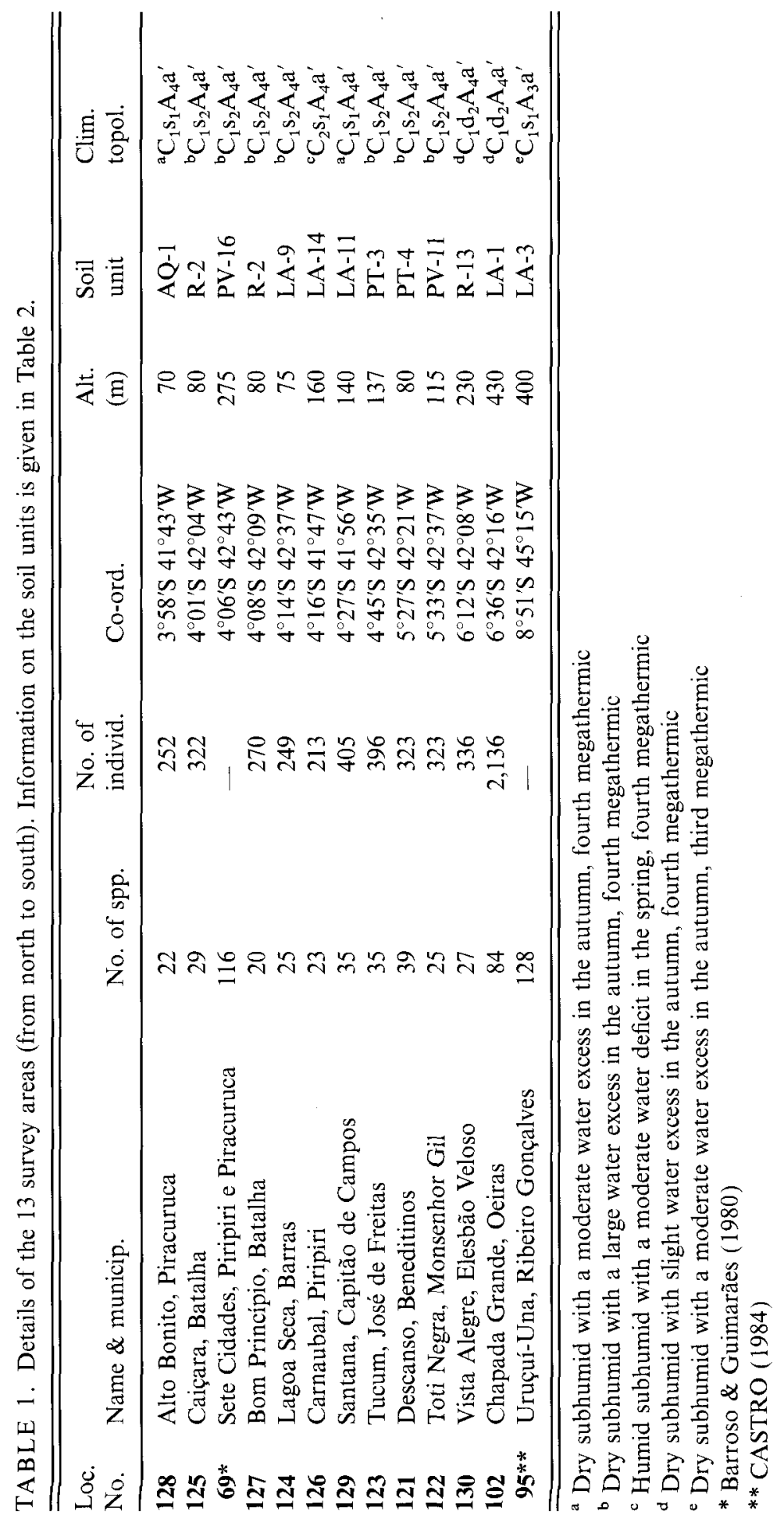


Furley et al., 1988; Fernandes \& Bezerra, 1990; Leitão Filho, 1992; Rodal, 1992, 1994), by examination of herbarium specimens and by personal communication.

Voucher specimens are deposited in the Graziela Barroso Herbarium (TEGB) of the Departamento de Biologia/Centro de Ciências Naturais/Universidade Federal do Piauí, Prisco Bezerra Herbarium (EAC) of the Departamento de Biologia/Centro de Ciências/Universidade Federal do Ceará, and Herbarium of the Departamento de Botânica/Instituto de Biologia/Universidade Estadual de Campinas (UEC).

Information on climatic elements and soils was obtained from Brasil (1990), Jacomine et al. (1986), Krishnan (1980), Lima et al. (1982), Nimer \& Brandão (1985, 1989), and Varejão-Silva \& Reis (1988). The hydric balance and the classification of the climate of each locality were determined according to Thornthwaite (1948) and Thornthwaite \& Mather (1955), following the instructions of Nimer \& Brandão $(1985,1989)$ and Varejão-Silva \& Reis (1988).

\section{PHYSICAL ENVIRONMENT}

All localities have a fair degree of climatic similarity with average annual temperature between $26.3^{\circ} \mathrm{C}$ and $27.0^{\circ} \mathrm{C}$, precipitation between $1,217 \mathrm{~mm}$ and $1,709 \mathrm{~mm}$, and annual average hydric deficiency between $365 \mathrm{~mm}$ and $560 \mathrm{~mm}$. They all fall into Thornthwaite's dry subhumid climatic type with the exception of locality 126 which just falls into his humid subhumid category (Table 1). The prevalence of subhumid climatic types in the localities studied is a consequence of the geographic position of the state of Piauí. They indicate the transition between the two great groups present in northern and northeastern Brazil, the Wet and Dry climates of Thornthwaite (1948). This transitional climatic character is expected, since the state is under both the northeastern influence, with its semiarid climate, and the Amazonian influence, with its superhumid climate (Azevedo \& Caser, 1980). The yearly total precipitation is similar to that of the bulk of the cerrado area in Brazil, and the climate shows a marked hydric seasonality, as it is highly megathermic all the year round and the rains are concentrated in a few months (December to April).

The soil mapping units to which each locality belongs are given in Table 1 and are described in Table 2. Most of the soils show evidence of hydric seasonality in the presence of concretions, plinthite, or light grey or yellow colours (Tables 1 and 2). Concretions and plinthite result most commonly from the interaction between iron, or iron and aluminium, and water in conditions of alternating soaking and drying, as can happen when the water-table shows great variation. Greyish colours may be produced by anaerobic conditions due to the elevation of the water-table, while yellow colours may indicate an excessive humidity with formation of goethite (when iron is present), but may also indicate low iron content and prevalence of kaolinite (Oliveira et al., 1992). The presence of Copernicia and Orbignya palms also indicates the influence of the soil water-table (Rizzini et al., 1988). The prevalence of soils showing the presence of a seasonally high water-table indicates that these Piauian cerrados may be classified closer to hyperseasonal savannahs than to purely 
TABLE 2. The soil mapping units found in the 13 survey areas, following Jacomine (1986).

\begin{tabular}{|c|c|c|c|}
\hline $\begin{array}{l}\text { Loc. } \\
\text { no. }\end{array}$ & $\begin{array}{l}\text { Soil } \\
\text { code }\end{array}$ & Soil type & Vegetation \\
\hline \multirow[t]{2}{*}{128} & \multirow[t]{2}{*}{ AQ-1 } & Quartz Sands & Subdeciduous cerrado \\
\hline & & Greyish Podzolics & Subdeciduous cerrado \\
\hline \multirow{3}{*}{$\begin{array}{l}125 \\
127\end{array}$} & \multirow[t]{3}{*}{$\mathbf{R}-2$} & Litholic soils & Subdeciduous cerrado \\
\hline & & $\begin{array}{l}\text { Concretionary Yellow-Red } \\
\text { Podzolics }\end{array}$ & Subdeciduous cerrado \\
\hline & & Plinthosols & $\begin{array}{l}\text { Subdeciduous cerrado/caatinga with } \\
\text { Orbignya }\end{array}$ \\
\hline \multirow[t]{2}{*}{69} & \multirow[t]{2}{*}{ PV-16 } & $\begin{array}{l}\text { Concretionary Yellow-Red } \\
\text { Podzolics }\end{array}$ & $\begin{array}{l}\text { Subdeciduous cerrado and transition to } \\
\text { caatinga }\end{array}$ \\
\hline & & Litholic soils & $\begin{array}{l}\text { Subdeciduous cerrado and transition to } \\
\text { caatinga }\end{array}$ \\
\hline \multirow[t]{2}{*}{124} & \multirow[t]{2}{*}{ LA-9 } & Yellow Latosols & $\begin{array}{l}\text { Subdeciduous cerrado, subdeciduous } \\
\text { forest/cerrado with and without } \\
\text { Orbignya }\end{array}$ \\
\hline & & Plinthosols & $\begin{array}{l}\text { Subdeciduous cerrado, subdeciduous } \\
\text { forest/cerrado with and without } \\
\text { Orbignya }\end{array}$ \\
\hline \multirow[t]{3}{*}{126} & \multirow[t]{3}{*}{ LA-14 } & Yellow Latosols (with pebbles) & $\begin{array}{l}\text { Subdeciduous cerrado with or without } \\
\text { Copernicia }\end{array}$ \\
\hline & & Concretionary Plinthosols & $\begin{array}{l}\text { Subdeciduous cerrado with or without } \\
\text { Copernicia }\end{array}$ \\
\hline & & $\begin{array}{l}\text { Indiscriminate assemblage } \\
\text { (Plinthosols, Greyish Podzols, } \\
\text { Quartz Sands) }\end{array}$ & $\begin{array}{l}\text { Subdeciduous cerrado with or without } \\
\text { Copernicia }\end{array}$ \\
\hline \multirow[t]{2}{*}{129} & \multirow[t]{2}{*}{ LA-11 } & Yellow Latosols & $\begin{array}{l}\text { Subdeciduous cerrado with or without } \\
\text { Copernicia, and transition to } \\
\text { subdeciduous forest }\end{array}$ \\
\hline & & Plinthosols & $\begin{array}{l}\text { Subdeciduous cerrado with or without } \\
\text { Copernicia, and transition to } \\
\text { subdeciduous forest }\end{array}$ \\
\hline \multirow[t]{2}{*}{123} & \multirow[t]{2}{*}{ PT-3 } & Plinthosols & Campo Maior complex* \\
\hline & & Solodic Planosols & Campo Maior complex* \\
\hline \multirow[t]{3}{*}{121} & \multirow[t]{3}{*}{ PT-4 } & Plinthosols & Campo Maior complex* \\
\hline & & Yellow-Red Podzolicss & Campo Maior complex* \\
\hline & & Litholic soils & Campo Maior complex* \\
\hline \multirow[t]{2}{*}{122} & \multirow[t]{2}{*}{ PV-11 } & $\begin{array}{l}\text { Concretionary Yellow-Red } \\
\text { Podzolics }\end{array}$ & $\begin{array}{l}\text { Subdeciduous forest with or without } \\
\text { Orbignya and transition to cerrado } \\
\text { with or without Orbignya }\end{array}$ \\
\hline & & Litholic soils & $\begin{array}{l}\text { Deciduous forest and transition to } \\
\text { subdeciduous cerrado }\end{array}$ \\
\hline \multirow[t]{2}{*}{130} & \multirow[t]{2}{*}{$\mathbf{R}-13$} & Litholic soils & $\begin{array}{l}\text { Hypoxerophyllous caatinga and } \\
\text { transition to deciduous cerrado }\end{array}$ \\
\hline & & Quartz Sands & $\begin{array}{l}\text { Hypoxerophyllous caatinga and } \\
\text { transition to deciduous cerrado }\end{array}$ \\
\hline
\end{tabular}


TABLE 2. (Continued).

\begin{tabular}{|c|c|c|c|}
\hline & & Planosols & Hypoxerophyllous caatinga with \\
\hline 102 & LA-1 & Yellow Latosols & $\begin{array}{l}\text { Subdeciduous cerrado and transition to } \\
\text { subdeciduous forest }\end{array}$ \\
\hline 95 & $\mathbf{L A}-\mathbf{3}$ & Yellow Latosols & Subdeciduous cerrado \\
\hline
\end{tabular}

* The Campo Maior complex is a mosaic of many vegetation types: campo cerrado, Copernicia savannah, floodplain grassland, parkland

seasonal ones (Sarmiento, 1984). Soils with light colours are not very frequent under cerrado vegetation, where predominantly reddish colours indicative of well-drained soils generally occur (Furley \& Ratter, 1988). Another important feature is that cerrado is a characteristic vegetation of calcium-poor dystrophic soils, while the presence of deciduous and subdeciduous forest and both Orbignya and Copernicia palms is linked to mesotrophic soils with higher calcium levels.

\section{RESULTS AND DISCUSSION}

Table 1 gives the number of species and individuals, the co-ordinates, altitude and soil type for each locality sampled. It shows that the three localities surveyed by nonstandardized methods showed the highest number of species. Localities 95 and 69 surveyed by the 'preferential collecting' method without reference to limited area or plant size qualification had 128 and 116 species respectively. Locality 102 , where the size qualification used was trunk only $\geq 3 \mathrm{~cm}$ diam. at ground level, contained no less than 2163 individuals of 84 species in 0.6 ha. The other 10 areas were all surveyed by the same method ( $\geq 5 \mathrm{~cm} \mathrm{DBH}$ on 1 ha plots of the same shape) and are thus directly comparable.

In these 10 areas the climate is very similar but there seems to be a relation of species diversity (richness) to soil type. It was greatest (loc. 121, 123, 129) where Plinthosols prevail in the mapping units and least (loc. 124, 126, 127, 128) where Latosols and Quartz Sands predominate, with intermediate levels (loc. 122, 125, 130 ) where Litholic Soils preponderate. The number of species $S$ was roughly proportional to the absolute density $\mathrm{N}$ (Table 1). Therefore, the soil mapping units may influence both the density and the species richness of the vegetation. In the present study the greatest species diversity was found in plots occurring in the Campo Maior complex (a very heterogeneous environment) and in areas of transition to subdeciduous forest, that is in the transition to better (more mesotrophic) soils. The least diversity was found in plots occurring in pure physiognomies of subdeciduous cerrado. Intermediate diversity was found in areas of transition to deciduous forest and to caatinga, that is in the transition to more xeric vegetation types.

The values of $\mathrm{N}$ in Table 1 indicate that the absolute density of thick-stemmed 
woody plants is not as high as that found in typical cerrado sensu stricto in Central Brazil (e.g. Furley et al., 1988), but is closer to that occurring on waterlogged or concretionary and rocky soils.

Of the 307 species encountered in the surveys only 22 occurred in $50 \%$ or more of the localities, and only Byrsonima crassifolia, Qualea grandiflora, Q. parviflora, Stryphnodendron coriaceum and Vatairea macrocarpa were present in all 13 surveys, thus indicating a great spatial heterogeneity of species composition in the cerrado vegetation in Piauí. This accords well with the high levels of heterogeneity recorded by Ratter \& Dargie (1992) in their survey of 26 areas of the cerrado biome throughout Brazil.

Table 3 lists the species and attempts to indicate their geographical distribution where sufficient information is available. Information on geographical distribution can be obtained for only about $60 \%$ of the total species listed in Table 3 , and is available in a very uneven fashion. Yet, although very speculative, some interpretation can be made of the known geographical distribution. Rizzini (1976) and Heringer et al. (1977) claimed that the cerrados of the states of Maranhão and Piauí have a very different woody flora from the central core area, the two areas having only about $50 \%$ of their species in common, and, for this reason, should be considered as a separate floristic or phytogeographic unit. Fernandes \& Bezerra (1990) designated the vegetation of these states as the Parnaiba Basin Sector of the Cerrado Province, thus stressing its individuality. Castro (1994) proposed the existence of eight diversity supercentres for Brazilian cerrados, one of them in the northeastern region of the cerrado biome, providing evidence based on the multivariate numerical analyses of many surveys. However, Table 3 shows that many species have wide geographic distribution in neotropical savannahs (Sarmiento, 1983). Some of these species (marked by ' $W$ ' in Table 3 and representing about 17\% of the species listed) have areas that extend far to the south and north. Others (marked by ' $\mathrm{S}$ ' in Table 3; about $22 \%$ of the species listed) have a large area of distribution to the south (Leitão Filho, 1992), with the cerrados of Piauí close to their northern limit. Yet others (marked by ' $\mathrm{N}$ '; about $6 \%$ ) extend further to the north, the Piauian cerrados representing roughly their southern limit. Some species (marked 'C'; about 16\%) are elements from the shrub-tree caatingas (Rodal, 1992, 1994), while others (marked 'A'; about 5\%) also occur in Amazon terra firme (noninundated) forests. Species marked ' $R$ ' (about $8 \%$ ) have their distribution restricted to the cerrados of Piaui and Maranhão. Finally, calcicolous species are indicated by ' $\mathrm{Ca}$ ' (about 4\%) since this soil preference is know to be important in determining species occurrence in cerrado habitats (Ratter et al., 1977, 1978). The percentages given above add up to more than the c.60\% of species for which information of geographic distribution is available since some species occur in more than one distribution category.

Our results show that the Piauian cerrados have some distinct characteristics of their woody flora, not found elsewhere, thus supporting, at least partially, the ideas of Fernandes \& Bezerra (1990), Heringer et al. (1977) and Rizzini (1976). The differences can even be observed at family level, e.g. Bombacaceae and Proteaceae, two important families in other areas that have not been found in our surveys in 
TABLE 3. Woody species of the cerrado vegetation of the state of Piaui, northeastern Brazil. Families according to Cronquist (1988). Code letters: W, wide distribution extending far north and south; $\mathrm{S}$, wide distribution to the south; $\mathrm{N}$, wide distribution to the north; $\mathrm{C}$, also found in shrub-tree caatinga; A, also found in terra firme (non-inundated) Amazonian forest; R, restricted distribution; $\mathrm{Ca}$, calcicolous species. (Available information on distribution is often incomplete so that future research may demonstrate that, for instance, an $\mathrm{S}$ may prove to be a W). Total: 60 families; at least 159 genera; 307 taxa.

\begin{tabular}{llllllllll}
\hline \hline Species & W & S & N & C & A & R & Ca \\
\hline
\end{tabular}

ANACARDIACEAE

Anacardium occidentale $L$.

Astronium fraxinifolium Schott

Myracrodruon urundeuva Allemão

Tapirira guianensis Aubl.

ANNONACEAE

Annona coriacea Mart.

Annona spp. ( 3 spp.)

Duguetia echinophora R.E.Fr.

Guatteria aff. minarum R.E.Fr.

Xylopia aromatica Mart.

APOCYNACEAE

Aspidosperma multiflorum A.DC.

A. pyrifolium Mart.

A. subincanum Mart. ex A.DC.

Aspidosmera s.p.

Hancornia speciosa M. Gómez

Himatanthus articulatus (Vahl) Woodson

H. obovatus (Müll.Arg.) Woodson

Peschiera affinis (Müll.Arg.) Miers

Rauvolfia ternifolia Kunth

Secondatia densiflora A.DC.

ARALIACEAE

Didymopanax sp.

ARECACEAE

Bactris sp.

Copernicia prunifera (Mill.) H.E. Moore

Mauritia martiana (Mart.) Burret

ASTERACEAE

Brickellia pinifolia A. Grey

Clibadium rotundifolium DC.

Trichogonia campestris Gardner

Vernonia fruticulosa Mart. ex DC.

Vernonia sp.

BIGNONIACEAE

Anemopaegma laeve DC.

Arrabidaea inaequalis Baill.

A. conjugata Mart.

Arrabidaea sp.

Cybistax antisyphilitica (Mart.) Mart.

Jacaranda brasiliana (Lam.) Pers. 
TABLE 3. (Continued).

J. jasminoides (Thunb.) Sandwith

Jacaranda spp. (2 spp.)

Tabebuia aurea (Manso) Benth. \& Hook.

T. ochracea (Cham.) Standl.

T. serratifolia (Vahl) Nicholson

Tabebuia spp. (2 spp.)

Zeyheria montana Mart.

Unknown (1 sp.)

BORAGINACEAE

Cordia superba Cham.

Cordia spp. (2 spp.)

BURSERACEAE

Protium heptaphyllum (Aubl.) Marchand

CACTACEAE

Cereus jamacaru DC.

CAESALPINIACEAE

Bauhinia cuyabensis (Bong.) Steud.

B. dubia Don

B. macrostachya Benth.

B. pulchella Benth.

B. rufa (Bong.) Steud.

Bauhinia spp. (2 spp.)

Caesalpinia ferrea Mart. ex Tul.

Cenostigma gardnerianum Tul.

Chamaecrista desvauxii (Colladon) Killip var.

langsdorffii (Kunth ex Vogel) H.S. Irwin

\& Barneby

Ch. desvauxii var. malacophylla (Vogel)

H.S. Irwin \& Barneby

Ch. juruenensis (Hoehne) H.S. Irwin \&

Barneby

Ch. rotundata (Vogel) H.S. Irwin \& Barneby

Ch. zygophylloides (Taub.) H.S. Irwin \&

Barneby

Chamaecrista sp.

Copaifera coriacea Mart.

C. luetzelburgii Harms

C. martii Hayne

Dimorphandra gardneriana Tul.

Hymenaea courbaril L. var. courbaril

H. courbaril var. stilbocarpa (Hayne) Lee \&

Langenh.

H. maranhensis Lee \& Langenh.

H. stigonocarpa Mart. ex Hayne

H. stigonocarpa var. pubescens Benth.

H. velutina Ducke

Martiodendron mediterraneum (Mart. ex

Benth.) Koeppen

Peltogyne confertiflora (Hayne) Benth. 
TABLE 3. (Continued).

Sclerolobium aureum (Tul.) Benth.

S. hypoleucum Benth.

S. paniculatum Vogel

Senna latifolia (G. Meyer) H.S. Irwin \& Barneby

S. macranthera DC. ex Colladon var.

pudibunda (Mart. ex Benth.) H.S. Irwin \&

Barneby

S. pendula (Willd.) H.S. Irwin \& Barneby

S. silvestris (Vell.) H.S. Irwin \& Barneby

S. trachypus (Benth.) H.S. Irwin \& Barneby

Senna sp.

CARYOCARACEAE

Caryocar coriaceum Wittm.

CECROPIACEAE

Cecropia cinerea Miq.

CELASTRACEAE

Maytenus sp.

CHRYSOBALANACEAE

Exellodendron gardneri (Hook.f.) Prance

Hirtella ciliata Mart. \& Zucc.

Hirtella sp.

Licania spp. (2 spp.)

CLUSIACEAE

Clusia microphylla Klotzsch ex Engl.

Kielmeyera sp.

Platonia insignis Mart.

Vismia guianensis (Aubl.) Choisy

V. magnoliifolia Cham. \& Schltdl.

Vismia sp.

COCHLOSPERMACEAE

Cochlospermum regium (Schrank) Pilg.

COMBRETACEAE

Buchenavia grandis Ducke

Combretum ellipticum Kuhlm.

C. fruticosum (Loefl.) Stuntz

C. leprosum Mart.

C. mellifluum Eichler

Terminalia fagifolia Mart. \& Zucc.

Terminalia sp.

Thiloa glaucocarpa (Mart.) Eichler

CONNARACEAE

Connarus suberosus Planch. var. suberosus

C. suberosus var. fulvus (Planch.) Forero

Connarus sp.

DILLENIACEAE

Curatella americana L.

Davilla cearensis Huber

D. aff. multiflora A. St.-Hil.

Davilla sp. 
TABLE 3. (Continued).

\section{EBENACEAE}

Diospyros brasiliensis Mart.

D. coccolobaeifolia Mart.

D. sericea A.DC.

ERYTHROXYLACEAE

Erythroxylum spp. (4 spp.)

EUPHORBIACEAE

Mabea fistulifera Mart.

Mabea sp.

Manihot coerulescens Pohl

M. pruinosa Pohl

Manihot sp.

Maprounea sp.

FABACEAE

Acosmium dasycarpum (Vogel) Yakovlev

Andira laurifolia Benth.

A. surinamensis (Boudt.) Splitz. ex Pulle

A. vermifuga (Mart). Benth.

Bowdichia virgilioides Kunth

Camptosema coriaceum (Nees \& Mart.)

Benth.

Dalbergia miscolobium Benth.

Deguelia nitidula (Benth.) A.-Tozz.

Dioclea glabra Mart. ex Benth.

D. reflexa Hook.f

Eriosema aff. congestum Benth.

Eriosema sp.

Harpalyce brasiliana Benth.

Lonchocarpus araripensis Benth.

Luetzelburgia auriculata (Allemão) Ducke

Machaerium acutifolium Vogel

M. opacum Vogel

Machaerium sp.

Pterocarpus violaceus Vogel

Pterodon emarginatus Vogel

Vatairea macrocarpa (Benth.) Ducke

Vigna firmula (Benth.) Maréchal, Mascherpa \&

Stainier

FLACOURTIACEAE

Casearia arborea (A. Rich.) Urb.

C. sylvestris $\mathrm{Sw}$.

Lindackeria latifolia Benth.

ICACINACEAE

Emmotum nitens (Benth.) Miers

HIPPOCRATEACEAE

Salacia micrantha (Mart.) Peyr.

Salacia spp. (3 spp.)

HUMIRIACEAE

Humiria balsamifera Aubl. 
TABLE 3. (Continued).

\section{KRAMERIACEAE}

Krameria argentea Mart. ex Spreng.

Krameria sp.

LAURACEAE

Ocotea sp.

Unknown (1 sp.)

LECYTHIDACEAE

Lecythis sp.

LOGANIACEAE

Antonia ovata Pohl

Mitreola sp.

Strychnos mitscherlichii M.R. Schonb. var.

amapensis Krukoff \& Barneby

LYTHRACEAE

Diplusudon $\mathrm{sp}$.

Lafoensia replicata Pohl

MALPIGHIACEAE

Banisteriopsis calcicola B. Gates

B. pubipetala (A. Juss.) Cuatrec.

B. stellaris (Griseb.) B. Gates var. latifolia

A. Juss.

Banisteriopsis spp. (2 species)

Byrsonima blanchetiana Miq.

B. crassifolia Kunth

B. sericea DC.

B. vacciniifolia A. Juss.

Byrsonima spp. (2 spp.)

Heteropterys sp.

Tetrapterys squarrosa Griseb.

Tetrapterys sp.

MALVACEAE

Hibiscus furcellatus Desr.

MARCGRAVIACEAE

Norantea sp.

MELASTOMATACEAE

Clidemia sp.

Leandra sp.

Miconia albicans (Swartz) Triana

M. theaezans (Bonpl.) Cogn.

Miconia sp.

Mouriri acutiflora Naudin

M. pusa Gardner

MENISPERMACEAE

Cissampelos $\mathrm{sp}$.

MIMOSACEAE

Calliandra abbreviata Benth.

C. parviflora Benth.

Chloroleucum foliolosum (Benth.)

G.P. Lewis ${ }^{1}$ 
TABLE 3. (Continued).

C. mangense (Jacq.) Britton \& Rosè

Enterolobium contortisiliquum (Vell.) Morong

E. schomburgkii (Benth.) Benth.

Enterolobium sp.

Inga fagifolia (L.) Willd. ex Benth.

I. scabriuscula Benth.

Mimosa acutistipula Benth.

M. caesalpiniifolia Benth.

M. pithecolobioides Benth. ${ }^{2}$

M. aff. somnians Humb. \& Bonpl. ex Willd.

M. verrucosa Benth.

Mimosa sp.

Parkia platycephala Benth.

Piptadenia moniliformis Pers.

Plathymenia foliolosa Benth.

P. reticulata Benth.

Stryphnodendron coriaceum Benth.

S. polyphyllum Mart.

Stryphnodendron sp.

MONIMIACEAE

Siparuna sp.

MORACEAE

Brosimum guianensis (Aubl.) Huber

Brosimum spp. (2 spp.)

Ficus gamelleira Kunth \& Bouché ex Kunth

Ficus sp.

MYRISTICACEAE

Virola sessilis (A.DC.) Warb.

V. surinamensis (Rol.) Warb.

MYRSINACEAE

Cybianthus sp.

MYRTACEAE

Campomanesia lineatifolia Ruiz \& Pav.

Eugenia punicifolia (Kunth) DC.

Eugenia spp. (2 spp.)

Myrcia hayneana Berg

M. obtusata (Schauer) Legrand

M. polyantha $\mathrm{DC}$.

M. tomentosa (Aubl.) DC. var. alloiota

(Berg) Legrand

Myrciaria aff. maragnensis Berg

Psidium spp. (3 spp.)

Unknown (1 sp.)

NYCTAGINACEAE

Guapira sp.

OCHNACEAE

Ouratea hexasperma (A. St.-Hil.) Baill.

Ouratea sp. 
TABLE 3. (Continued).

OLACACEAE

Ximenia americana $\mathrm{L}$.

OPILIACEAE

Agonandra brasiliensis Miers

PASSIFLORACEAE

Passiflora foetida L.

P. haematostigma Mart.

P. kermesina Link

Passiflora sp.

POLYGALACEAE

Bredemeyera floribunda Willd.

Securidaca volubilis $L$.

RUBIACEAE

Alibertia concolor (Cham.) Schum.

A. edulis (L. Rich.) A. Rich.

A. obtusa Schum.

A. sessilis (Vell.) Schum.

Chomelia obtusa Cham. \& Schltdl.

Genipa americana $L$.

Guettarda angelica Mart. ex Müll.Arg.

Palicourea sp.

Psychotria $\mathrm{sp}$.

Thieleodoxa lanceolata Cham.

Tocoyena formosa (Cham. \& Schltdl.) Schum.

ssp. formosa

T. formosa ssp. tomentosa (Mart.) A.L. Prado

Tocoyena $\mathrm{sp}$.

SAPINDACEAE

Allophylus quercifolius (Mart.) Radlk.

Allophylus sp.

Cupania revoluta Radlk.

Magonia pubescens A. St.-Hil

Serjania caracasana (Jacq.) Willd.

S. marginata Casar.

Unknown (1 sp.)

SAPOTACEAE

Manilkara spp. (2 spp.)

Pouteria ramiflora (Mart.) Radlk.

SIMAROUBACEAE

Simaba warmingiana Engl.

Simarouba versicolor A. St.-Hil.

SOLANACEAE

Solanum baturitense Huber

S. cordifolium Dunal

S. macranthum Dunal

STERCULIACEAE

Helicteres sacarolha A. St.-Hil.

Sterculia striata A. St.-Hil. \& Naudin

Sterculia $\mathrm{sp}$. 
TABLE 3. (Continued).

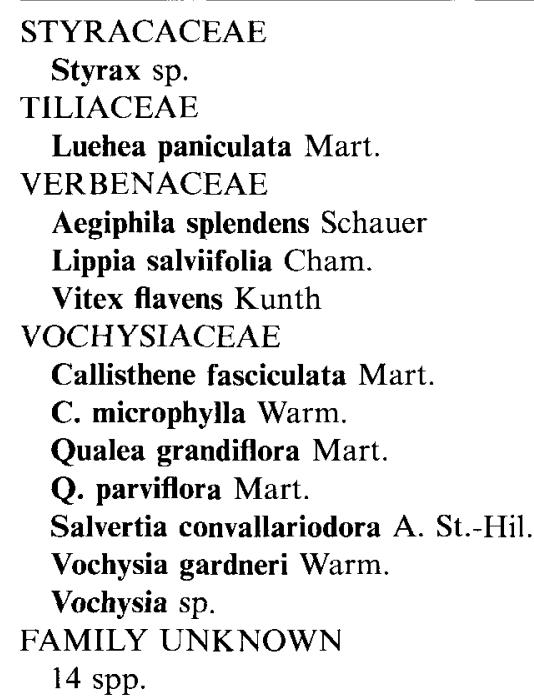

${ }^{1}$ Chloroleucon foliolosum (Benth.) G.P. Lewis (= Pithecellobium foliolosum Benth.).

${ }^{2}$ Mimosa pithecolobioides Benth. (=M. lasiophylla Benth.).

Piauí. However, our research on the geographical distribution of species does not support the high degree of species endemism claimed by Rizzini (1976) and Heringer et al. (1977). Such claims must be considered against the background of extremely high floristic heterogeneity throughout the cerrado region: Castro (1994) found that about $40 \%$ of all woody species occurred at only a single locality out of the total of 145 which he compared. In fact, the number of probably endemic woody species in the Piauian cerrados is no greater than that found by Castro (1994) in other areas of the Brazilian cerrados. This, together with the high proportion of species with wide geographic distribution, suggests that the Piauian cerrados were not isolated from other cerrados areas for any long period during evolution.

\section{ACKNOWLEDGEMENTS}

Financial support for the project was provided by FAPESP (Foundation for Science Support of the State of São Paulo), CNPq (National Council of Scientific and Technological Development), SUDENE (Superintendency for the Development of the Northeastern Region), and GTZ (Deutsche Gesellschaft für Technische Zusammenarbeit). The authors are indebted to the staff of the Departamento de Botânica/Universidade Estadual de Campinas, and particularly to Professors Hermógenes de Freitas Leitão Filho (recently deceased) and Jorge Yoshio Tamashiro for helping in the taxonomic identification. We thank Drs James Ratter and Peter Furley for comments, and Esmeralda Zancheta Borghi and Emílio de Santana for drawing Fig. 1. 


\section{REFERENCES}

AZEVEDO, L. G. de \& CASER, R. L. (1980). Regionalização do cerrado. In: MARCHETTI, D. \& MACHADO, A, D. (coord.). Cerrado: uso e manejo. Brasília, Editerra. V Simpósio sobre o Cerrado, pp. 211-230. Brasília: Universidade de Brasília.

BARROSO, G. M. \& GUIMARÃES, E. F. (1980). Excursão botânica ao Parque Nacional de Sete Cidades, Piauí. Rodriguésia 32 (53): 241-267.

BRASIL. Ministério do Interior. Superintendência do Desenvolvimento do Nordeste. (1990). Dados pluviométricos mensais do Nordeste; Estado do Piauí. Recife: SUDENE/ DPG/HME, 236 pp. (Pluviometria, 2).

CASTRO, A. A. J. F. (1984). Vegetação e flora da Estação Ecológica de Uruçuí-Una (Resultados preliminares). Anais Congresso Nacional de Botânica 36: 251-261.

CASTRO, A. A. J. F. (1994). Comparação florístico-geográfica (Brasil) e fitossociológica (Piaui São Paulo) de amostras de Cerrado. PhD thesis. Universidade Estadual de Campinas. São Paulo, Brazil.

CEPRO. Fundação Centro de Pesquisas Econômicas e Sociais do Piauí. (1992). Cerrados piauienses: estudo preliminar de suas potencialidades. Teresina: CEPRO, $63 \mathrm{pp}$.

COUTINHO, L. M. (1978). O conceito de cerrado. Revista Brasileira de Botânica 1 (1): $17-23$.

CRONQUIST, A. (1988). The evolution and classification of flowering plants. 2nd edn. New York: New York Botanical Garden, 555pp.

FER NANDES, A. G. \& BEZERRA, P. (1990). Estudo fitogeográfico do Brasil. Fortaleza: Stylus Comunicações, 205pp.

FURLEY, P. A. \& RATTER, J. A. (1988). Soil resources and plant communities of the central Brazilian cerrado and their development. Journal of Biogeography 15: 97-108.

FURLEY, P. A., RATTER, J. A. \& GIFFORD, D. R. (1988). Observations on the vegetation of eastern Mato Grosso, Brazil III. The woody vegetation and soils of the Morro de Fumaça, Torixoreu. Proc. R. Soc. Lond. B 235: 259-280.

GOERGEN, J. (1983). Critérios ecológicos para o desenvolvimento de modelos de aproveitamento agrícola adaptados a regiões das chapadas no Piaui central, Brasil. Teresina: DNOCS/GTZ, 243pp. (Mimeographed).

HERINGER, E. P., BARROSO, G. M., RIZZO, J. A. \& RIZZINI, C. T. de (1977). A flora do cerrado. In: FERRI, M. G. (coord.). IV simpósio sobre o cerrado, pp. 211-232. São Paulo: EDUSP; Belo Horizonte: Italiaia.

JACOMINE, P. K. T. (coord.). (1986). Levantamento exploratório de reconhecimento de solos do estado do Piaui. 2 vol. Rio de Janeiro, EMBRAPA/SNLCS. Recife: SUDENE/DRN, 782pp.

JENR ICH, H. (1989). Vegetação arbórea e arbústea nos altiplanos das chapadas do Piauí central; Caracteristicas, ocorrências e empregos. Teresina: DNOCS/GTZ.

KRISHNAN, A. (1980). Agroclimatic classification methods and their application to India. In: VIRMANI, S. M., SIVAKUMAR, M. V. K., ROSENBERG, G., KUMBLE, V. (eds.). Climatic classification: a consultant's meeting. Patanchern: ICRISAT, pp. 59-88.

LEITÃo FILHO, H. de F. (1992). A flora arbórea dos cerrados do estado de São Paulo. Hoehnea 19: 151-163.

LiMA, M. G. de, AlENCAR, P. A. M. de \& COELHO, H. (1982). Normais de temperaturas máxima, mínima e média estimadas em função de latitude, longitude e altitude para o estado do Piauí. Ensaios. Boletim de Pesquisa 1: 9-37.

MUELLER-DOMBOIS, D. \& ELLENBERG, H. (1974). Aims and methods of vegetation ecology. New York: John Wiley and Sons, 547pp. 
NIMER, E. \& BRANDÃO, A. M. P. M. (1985). Balanço hídrico anual a partir de valores normais e tipologia climática. Revista Brasileira de Geografia 47 (3/4): 373-416.

NIMER, E. \& BRANDÃO, A. M. P. M. (1989). Balanço hidrico e clima da região dos cerrados. Rio de Janeiro: IBGE, 166pp.

OLIVEIRA, J. B. de; JACOMINE, P. K. T. \& CAMARGO, M. N. (1992). Classes gerais de solos do Brasil; Guia auxiliar para seu reconhecimento. Jaboticabal: FUNEP, 201pp.

RATTER, J. A. \& DARGIE, T. C. D. (1992). An analysis of the floristic composition of 26 cerrado areas in Brazil. Edinb. J. Bot. 49: 235-250.

RATTER, J. A., RICHARDS, P. W., ARGENT, G. \& GIFFORD, D. R. (1973). Observations on the vegetation of northeastern Mato Grosso I. The woody vegetation types of the Xavantina-Cachimbo Expedition area. Phil. Trans. R. Soc. B 266: $449-492$.

RATTER, J. A., ASKEW, G. P., MONTGOMERY, R. F. \& GIFFORD, D. R. (1977). Observações adicionais sobre o cerradão de solos mesotróficos no Brasil Central. In: FERRI, M. G. (coord.). IV Simpósio sobre o Cerrado, pp. 303-316. São Paulo, Brazil.

RATTER, J. A., ASKEW, G. P.; MONTGOMERY, R. F. \& GIFFORD, D. R. (1978). Observations on forests of some mesotrophic soils in Central Brazil. Revista Brasileira de Botânica 1: 47-58.

RATTER, J. A., BRIDGEWATER, S., ATKINSON, R. \& RIBEIRO, J. F. (1996). Analysis of the floristic composition of the Brazilian cerrado vegetation II: Comparison of the woody vegetation of 98 areas. Edinb. J. Bot. 53: 153-180.

RIZZINI, C. T. de. (1963). A flora do cerrado; Análise florística das savanas centrais. In: FERRI, M. G. (org.). Simpósio sobre o cerrado: pp. 105-202. São Paulo: Edgard Blücher/EDUSP.

R IZZIN I, C. T. de. (1976). Contribuição ao conhecimento das floras nordestinas. Rodriguésia 28 (41): 137-193.

RIZZINI, C. T. de, COIMBRA FILHO, A. F. \& HOUAISS, A. (1988). Ecossistemas brasileiros/Brazilian ecosystems. Rio de Janeiro: Index, 200pp.

RODAL, M. J. N. (1992). Fitossociologia da vegetação arbustivo-arbórea em quatro áreas de caatinga em Pernambuco. PhD thesis. Universidade Estadual de Campinas. São Paulo, Brasil.

RODAL, M. J. N. (1994). Lista de familias e espécies arbustivas e arbóreas depositadas nos herbários da Empresa Pernambucana de Pesquisa Agropecuária (IPA), professor Vasconcelos Sobrinho (PEUFR) e Universidade Federal de Pernambuco (UFP). Recife: Universidade Federal Rural de Pernambuco, 15pp. (Reprographed).

SARMIENTO, G. (1983). The savannahs of tropical America. In: BOURLIÉRE, F. (ed.). Tropical Savannahs. Amsterdam: Elsevier, pp. 245-288.

SARMIENTO, G. (1984). The Ecology of Neotropical Savannahs. Cambridge, USA: Harvard University Press, 235pp.

THORNTHWAITE, C. W. (1948). An approach towards a rational classification of climate. Geographic Review 38 (1): 55-94.

THORNTHWAITE, C. W. \& MATHER, J. R. (1955). The water balance. Publication of Climatology 8 (1): 1-104. Laboratory of Climatology, Centerton, New Jersey University, USA.

VAREJÃO-SILVA, M. A. \& REIS, A. C. de S. (1988). Agrometeorologia e climatologia tropicais, pp. 86-89. Módulo 1.1. Brasília, ABEAS. 